\title{
〔技術ノート〕
}

\section{全自動サンプリング方式キャピラリー電気泳動装置 $(A C-2001)$ を用いた遺伝子診断応用における基礎的評価}

\author{
柳澤利枝*・須藤加代子**・秋月㩒子**・鎌田直幸 $* * *$ \\ 佐野恵一***・真柄直郎 $* *$
}

はじめに

PCR や RFLPを用いた遺伝子診断の解析には，通 常アガロースゲルあるいはポリアクリルアミドゲルな ぞを支持体としたスラブゲル電気泳動法が用いられて いる．スラブゲル電気泳動法は, 比較的扱いが簡便で あるだけでなく, 幅広い分子量の遺伝子解析に適して いるが，ゲル作成やサンプル注入などの操作が煩雑で あることや，泳動時間が長いなどの欠点もある。

キャピラリー電気泳動法 (以下 $\mathrm{CE}$ ) は, 高分解 能, 高速分析という利点に加えて, サンプリングから データ解析までの全自動化が可能であり，今後の遺伝 子解析において注目すべき分析手段になり得ると考元 られる1,2).

本報では，全自動サンプリング方式キャピラリー電 気泳動装置（AC-2001）に関する基礎的デー夕を得る ことを目的として, 同時再現性, 分解能および検出感 度について検討するとともに，実際の遺伝子診断への 応用として, 肝機能検査として広く用いられている低 コリンエステラーゼ血症例の変異遺伝子を解析した結 果を併せて報告する。

\section{対象および方法}

\section{1. 測定方法}

装置は AC-2001（常光）を使用した。キャピラリ 一カラムはポリイミドでコーティングした長さ $70 \mathrm{~cm}$ のフューズドシリカ（内径 $100 \mu \mathrm{m} ）$ 製のものを用い た. 泳動溶液は，0.5\%（w/v）メチルセルロースを $50 \mathrm{mM}$ トリスホウ酸バッファー $(\mathrm{pH} 8.3)+2.5$ mM EDTA に溶解したものを用い, インターカレー ターとして Molecular Dye (Advanced Molecular Systems）を終濃度 $0.01 \%$ （v/v）になるように添加 した。サンプル注入は， $3 \mathrm{kV}, 100 \mathrm{sec}$ の条件で電気 的に注入した。泳動条件は $20 \mathrm{kV}, 30 \mathrm{~min}$ とし, 外 部の循環式冷却装置によりキャピラリーカラムを $20^{\circ} \mathrm{C}$ に温度設定した. DNA の検出には蛍光フォトダ イオードアレイを, 光源はキセノンランプを使用し, 励起波長 $488 \mathrm{~nm}$ ，検出波長 $519 \mathrm{~nm}$ で測定した。

\section{2. 同時再現性}

同時再現性は， $\phi \mathrm{X} 174$ を Hae IIIで消化した DNA 断片（Advanced Molecular Systems）を用い，これ を 22 回連続測定し, 各ピークのマイグレーションタ イムの CV\%值を算出することにより評価した。

\section{3. 分解能評価}

分解能については, pBR 322 を Msp I で消化した

Application of capillary electrophoresis apparatus (AC-2001) equipped with automatic sampling tubes to certain routine genetic diagnoses.

* Rie Yanagisawa； (株) 常光試薬機器部

** Kayoko Sudo, Setsuko Akizuki, Tadao Magara ; 東京慈恵会医科大学第三病院臨床検査医学

*** Naoyuki Kamata, Keiichi Sano ; (株) 常光開発部

Correspondence address: Keiichi Sano, Jokoh Co., Ltd., 3-19-4, Hongo, Bunkyo-ku, Tokyo 113, Japan.

略号一覧：PCR, polymerase chain reaction; RFLP, restriction fragment length polymorphism; CE, capillary electrophoresis.

（受付 1996 年 11 月 18 日，受理 1997 年 1 月 7 日，刊行 1997 年 4 月 15 日） 
DNA（New England Biolabs）を泳動し，その泳動 パターンにより評価した。

\section{4. 検出感度試験}

比較対照としては，アガロースミニスラブゲル電気 泳動（コスモバイオ）を用いた。解析にはコリンエス テラーゼ遺伝子のエクソン 2 のローカス $3^{3)}$ (324 bp）と c-ki-ras/コドン $12 （ 108$ bp）を増幅した PCR 産物（TaKaRa）を使用した。この PCR 産物を 2 倍 希釈系列で測定し，ピークあるいはバンドとして同定 可能な濃度で評価した。

なお， $\mathrm{CE}$ で測定する場合，電気的注入法では PCR のバッファーに含まれる塩が注入量を変化させる可能 性がある.このため, PCR 産物を滅菌水で希釈した 後, 限外万過膜を用いて遠心操作により脱塩した.ア ガロースゲル電気泳動は，2\%および $3 \%$ のゲルにサ ンプルを $8 \mu 1$ 塗布した後, 電気泳動に供した。その 後, エチジウムブロマイドで染色し，UV 照射下で DNA の位置を確認した。なお，両方法での注入条件 あるいは検体塗布量は, 通常泳動する時の条件を用い た.

\section{5. 低コリンエステラーゼ血症例の遺伝子解析}

本解析には, 低コリンエステラーゼ血症例の一つで G365R 変異をもつへテロ接合体を対象として用いた。 なお，PCR および制限酵素処理は Maekawa ら ${ }^{4)} の$ 報告に従った。G 365 R は，特に日本人に頻度が高い とされる変異で，コドン 365 が GGA（グリシン）か ら CGA（アルギニン）にミスセンス変異している (Fig. 1).この変異により, Taq I 制限酵素切断サイ ト TCGA が生じ, $184 \mathrm{bp}$ と $162 \mathrm{bp}$ にこの遺伝子が 切断される。なお今回用いたプライマーは, G365R
変異だけでなく, コドン 418 の $\mathrm{T}$ から Cへの点突然 変異もともに検出できるようにデザインされており， 366 bp のフラグメントが増幅される。このプライマ 一を用いて PCR を行い，Taq I で制限酵素処理する ことにより，今回の遺伝子診断対象である G365R の ヘテロ接合体は, $184 \mathrm{bp}, 162 \mathrm{bp}, 346 \mathrm{bp}, 20 \mathrm{bp}$ の 断片に切断されることになる。

\section{結 果}

\section{1. 同時再現性}

$\phi \mathrm{X}$ 174-Hae III 消化物を CE 泳動した時のエレクト ロフェログラムを Fig. 2ak示した. 各ピークのマイ グレーションタイムの再現性は, $\mathrm{CV} \%$ 值にして平均 $7.74 \%(n=22)$ であった。

\section{2. 分解能}

次に $\mathrm{pBR} 322-M s p$ I 消化物を CE 泳動した結果, $238 \mathrm{bp}$ と $242 \mathrm{bp}$ の差異 $(4 \mathrm{bp}$ ) が, 本法で分離可能で あった (Fig. 2 b).

\section{3. 検出感度試験}

検出感度は，ゲルと AC-2001 で泳動を行った結果, いずれの方法でも 8 倍希釈まで検出可能であった.

\section{4. 低コリンエステラーゼ血症例の遺伝子解析結果} サンプルを制限酵素処理をしない時, 366 bp のピ ークのみが認められたが, Taq I で制限酵素処理す ることにより, $346 \mathrm{bp}$ と $184 \mathrm{bp}, 162 \mathrm{bp}$ のピークが 得られた。この成績は, 本実験に用いた遺伝子が, G365R 変異をもつへテロ接合体であることを示すも のである（Fig. 3a，b).なお，この実験で出現する 最も低分子の断片は，プライマーおよび dNTPsであ ると考えられた。
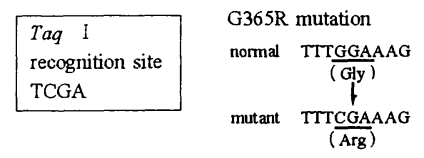

common primer
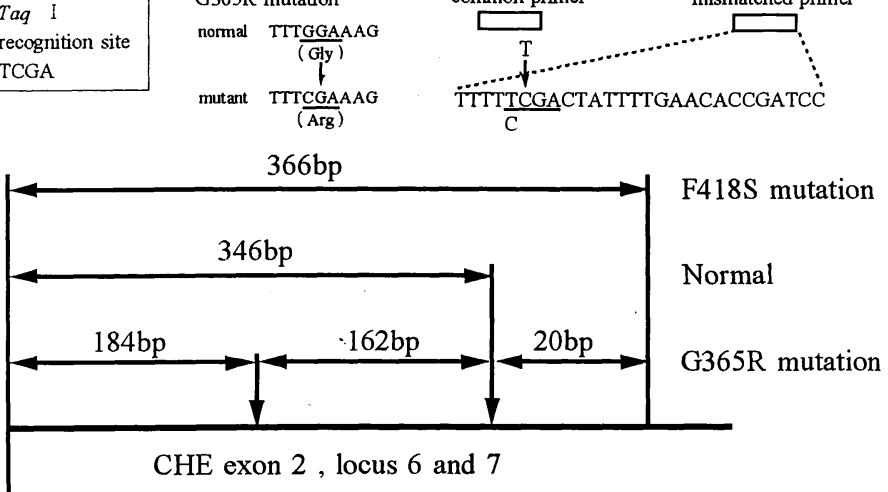

Fig. 1. Mismatched PCR to detect the misssense mutation of G365R mutation (and F418S). 


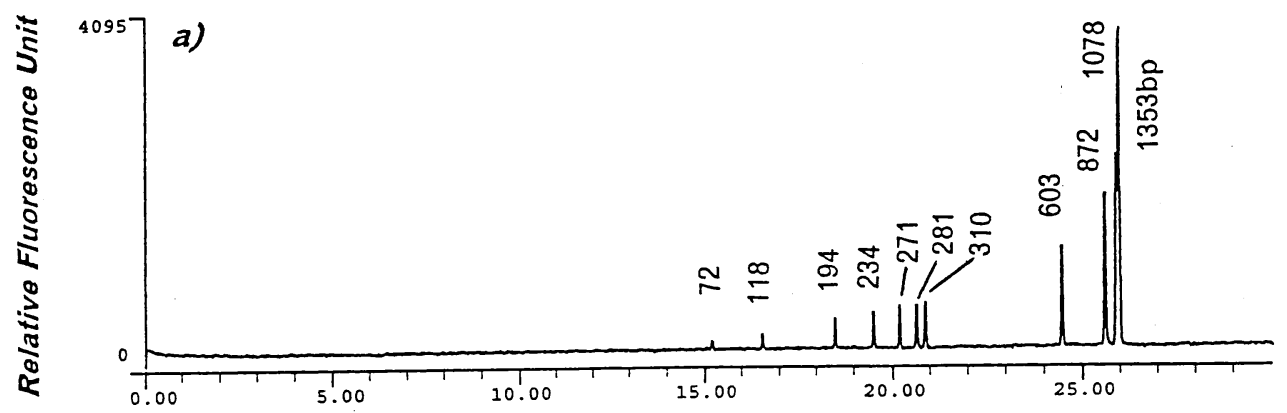

Migration Time (min.)

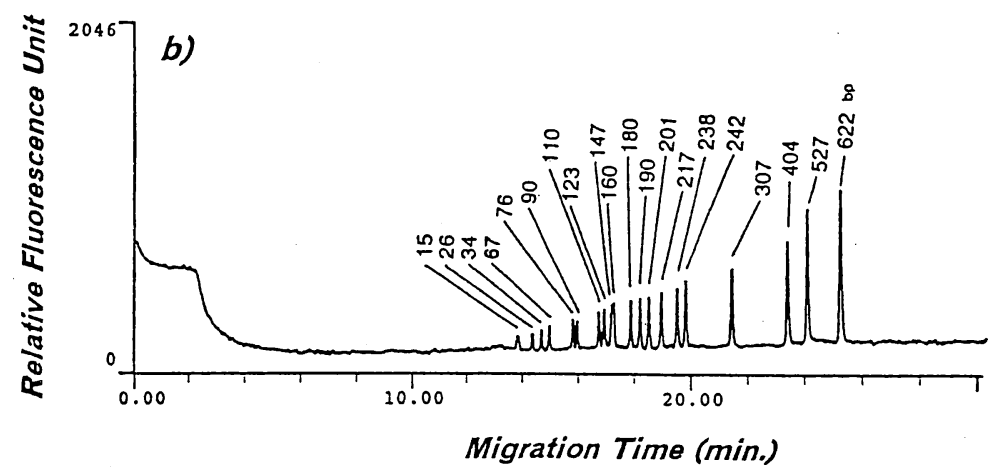

Fig. 2. Separation of double strand DNA restriction fragment mixture by capillary electrophoresis.

a) Separation of Hae III digested $\phi$ X 174 RF DNA, b) Separation of Msp I digested pBR322.

\section{考 察}

今回われわれは，AC-2001 の遺伝子診断における 基礎的データを得ることを目的として解析を実施し た。

$\phi \mathrm{X}$ 174-Hae III消化物を CE 泳動し，同時再現性に ついて検討した結果, 各ピークのマイグレーションタ イムのCV\%值は7〜8\%とばらつきがみられた。 PCR 産物あるいは SSCP を解析する場合では, マイ グレーションタイムの再現性が重要であることから, キャピラリー内壁のコーティングあるいは温度制御装 置5) の改良を進めていく必要がある. 今回の成績から みた分解能は, $238 \mathrm{bp}$ と $242 \mathrm{bp}$ のわずか $4 \mathrm{bp}$ の差異 の分離が可能であったが，より再現性の向上が要求さ れる。また，目的とするDNA の断片長により電圧あ るいはポリマーの濃度などを考慮する必要があり，今 回使用したポリマーは，150〜300 bp の DNA の分離 に適していると考えられた。検出感度は, アガロース
ゲル電気泳動と AC-2001 で PCR 産物を希釈系列で分 析した結果, 同じ希釈率まで検出可能だった。 CEで

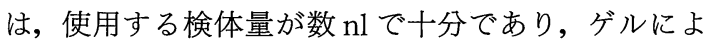
る分析より微量で同程度の感度が得られるが, 実際に は測定に数 $\mu 1$ のサンプル量が必要であることから, この容量をいかに少なくするかが今後の課題である.

次に遺伝子診断への応用として, 低コリンエステラ 一ゼ血症例の遺伝子解析を試みた結果, 制限酵素処理 をしない時, $366 \mathrm{bp}$ のピークのみが認められたが, Taq I で制限酵素処理すると, $346 \mathrm{bp}$ と $184 \mathrm{bp}, 162$ bpのピークが検出された。このことから，G365Rの ヘテロ接合体であることが正しく確認され，本装置は 遺伝子診断にも十分に有用であると考えられた。

遺伝子診断における自動機器の導入は, 多数検体処 理が可能であるだけではなく, 従来法で問題とされて いた個人差によるデータのばらつきなどの問題点の改 善にも有効である. 以上のことから本装置は, 日常の臨 床検査や臨床遺伝子診断への適用が今後期待される. 


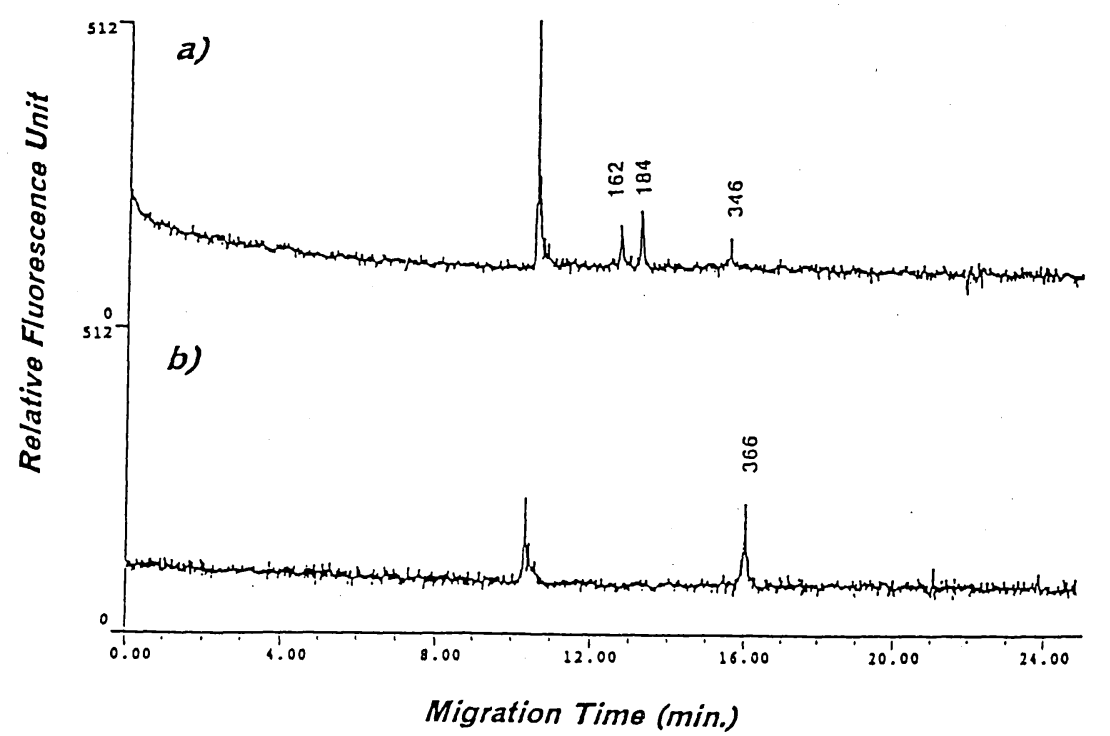

Fig. 3. Electropherogram for detecting the PCR-RFLP analysis of G365R mutation.

a) Taq I digestion, b) no digestion.

本稿の要旨は, 第 47 回日本電気泳動学会総会（秋 田）にて発表した。

\section{文献}

1) Smith LM. High-speed DNA sequencing by capillary gel electrophoresis. Nature 1991; 349 (28) : 812-3.

2) Arakawa H, Uetanaka K, Maeda M, Tsuji A, Matsubara Y, Narisawa K. Analysis of polymerase chain reaction-product by capillary electrophoresis with laser-induced fluorescence detection and its application to the diagnosis of medium-chain acryl-coenzyme A dehydrogenase deficiency. J Chromatogr (A) 1994; 680 : $517-23$.
3) Sudo K, Maekawa M, Kanno T, Akizuki S, Magara T. Three different point mutations in the butyrylcholinesterase gene of three Japanese subjects with a silent phenotype: possible Japanese type alleles. Clin Biochem $1996 ; 29(2): 165-9$.

4) Maekawa M, Sudo K, Kanno T, Kotani K, Dey DC, Ishikawa J, Izumi M, Etoh K. Genetic basis of the silent phenotype of serum butylcholinesterase in three compound heterozygotes. Clin Chim Acta 1995 ; 235 : 41-57.

5) Arakawa H, Nakashiro S, Maeda M, Tsuji A. Analysis of single-strand DNA conformation polymorphism by capillary electrophoresis. J Chromatogr (A) 1996; 722 : 359-68. 